\title{
EFFICIENCY OF EFFLUENT TREATMENT OF MEATPACKING AND TEXTILE PLANTS, IN PHYSICAL, CHEMICAL AND TOXICOLOGICAL TERMS
}

\author{
Eficiencia del tratamiento de efluentes de plantas de carne y plantas textiles, en términos físicos, químicos y toxicológicos
}

\author{
Michelli FONTANA, Rafael LOPES TURINO, Ivane BENEDETTI TONIAL, \\ Ticiane SAUER POKRYWIECKI and Elisângela DÜSMAN*
}

Universidade Tecnológica Federal do Paraná, Departamento Acadêmico de Química e Biología, Linha Santa Bárbara s/n, CEP 85601-970 - Caixa Postal 135 - Francisco Beltrão - PR - Brasil

*Corresponding author: edusman@utfpr.edu.br

(Received: August 2018; accepted: August 2019)

Key words: Allium cepa L., Artemia salina L., meatpacking effluent, textile effluent, toxicity

\begin{abstract}
The disposal of untreated effluents directly affects the water quality of the receiving medium, which can cause damage to the aquatic ecosystem and to human health. Therefore, the objective of this study was to analyze the toxicity and the physical and chemical parameters of raw and treated effluents of a meatpacking and a textile plant, in order to evaluate the effectiveness of the treatment. Thus, cytotoxic tests with Allium cepa L. and the immobility/mortality test with Artemia salina L., besides the physical and chemical tests of $\mathrm{pH}$, ammoniacal nitrogen, oxygen demand, total solids, chlorides and alkalinity were used. The immobility/mortality test with Artemia salina L. revealed the absence of dead organisms in the tested low concentrations of raw and treated meatpacking and textile effluents. However, the highest concentrations of raw meatpacking effluents $(50 \%$ and $100 \%)$ and treated meatpacking effluents $(100 \%)$ caused the mortality of organisms. Raw and treated textile effluents were statistically toxic only at the highest concentration evaluated (100\%). Furthermore, the raw and treated effluents of the meatpacking and textile plants were not cytotoxic in the test with Allium cepa $\mathrm{L}$. The results of the physicochemical analyses proved the effectiveness of the treatment of the meatpacking effluents in terms of diminished $\mathrm{pH}$, ammoniacal nitrogen, chemical oxygen demand, and total solids. And the raw effluents from the textile plant also exhibited a reduction in $\mathrm{pH}$, chlorides, alkalinity and total solids. The treatments were effective for these effluents, but still had a toxic effect on A. salina. Thus, it is indicated that additional treatment should be carried out in the textile and meatpacking effluents, emphasizing the importance of adequate treatment systems to prevent environmental harm and public health problems.
\end{abstract}

Palabras clave: Allium cepa L., Artemia salina L., efluente de empacado de carne, efluente textil, toxicidad

\section{RESUMEN}

La liberación de efluentes no tratados afecta directamente la calidad del agua del medio receptor, pudiendo traer perjuicios al ecosistema acuático y también a la salud humana. Por lo tanto, el objetivo de este estudio fue analizar la toxicidad y los parámetros fisicoquímicos del efluente con y sin tratamiento de una planta textil y una empacadora 
de carne, a fin de evaluar la efectividad del tratamiento utilizado. Se utilizaron pruebas citotóxicas con Allium cepa L. y la prueba de inmovilidad/mortalidad con Artemia salina L., además de las pruebas físicas y químicas de $\mathrm{pH}$, nitrógeno amoniacal, demanda de oxígeno, sólidos totales, cloruros y alcalinidad. La prueba de inmovilidad $/ \mathrm{mortalidad}$ con Artemia salina L. reveló la ausencia de organismos muertos en las bajas concentraciones probadas de los efluentes en bruto y tratados de la empacadora y la fábrica textil. Sin embargo, las concentraciones más altas de los efluentes no tratados de la empacadora de carne $(50$ y $100 \%)$ y los efluentes tratados de dicha planta $(100 \%)$ causaron la mortalidad de organismos. Los efluentes de la fábrica textil tratados y sin tratamiento fueron estadísticamente tóxicos sólo en la mayor concentración evaluada $(100 \%)$. Además, los efluentes con y sin tratamiento de ambas plantas no fueron citotóxicos en la prueba con Allium cepa L. Los resultados de los análisis físicos y químicos demostraron la efectividad del tratamiento de los efluentes de la empacadora de carne en términos de $\mathrm{pH}$ disminuido, nitrógeno amoniacal, demanda química de oxígeno y sólidos totales. Y los efluentes sin tratar de la planta textil también mostraron una reducción en el $\mathrm{pH}$, cloruros, alcalinidad y sólidos totales. Los tratamientos fueron efectivos para estos efluentes, pero aún así tuvieron un efecto tóxico sobre A. salina. Por lo tanto, está indicado realizar un tratamiento adicional en los efluentes de ambas plantas, enfatizando la importancia de contar con sistemas de tratamiento adecuados para prevenir daños ambientales y problemas de salud pública.

\section{INTRODUCTION}

One of the main sources of water resource contamination is the disposal of domestic and industrial effluents. These effluents compromise the quality of the entire aquatic ecosystem (Earnhart 2013, Kamali et al. 2019). In particular, liquid industrial effluents contain organic matter and inorganic chemical compounds that are hazardous and toxic to any kind of life, whether aquatic or not. The inability of industries to meet the effluent discharge standards and regulations can negatively affect the environment (Prabakar et al. 2018).

Given the context of industrial activities and based on the reports of Mathur et al. (2007), Sharma et al. (2007) and Noreen et al. (2017), the textile sector is considered the most polluting sector. According to Silva et al. (2004), every year $12 \%$ of synthetic dyes used in textile production are wasted and dumped into the environment, damaging the photosynthetic processes in water channels.

Moreover, these effluents have a complex chemical composition, with large amounts of suspended solids, high chemical oxygen demand (COD) and biochemical oxygen demand (BOD), and high temperatures, acidity and/or alkalinity (Liu et al. 2007, Noreen et al. 2017, Costa et al. 2018). They also contain anti-foaming agents and humectants, oils, metals, and other organic compounds used in the various stages of dyeing (Silva et al. 2004, Liu et al. 2007, Mathur et al. 2007, Noreen et al. 2017).
In addition to the textile industry, the food industry has also contributed to the rising pollution of water resources. In recent years, the increasing population has led to a growing demand for meat and the enhancement of slaughter and meat industrialization techniques, which generate large volumes of wastewater with highly polluting characteristics (Sperling 2007, Maldaner 2008).

Regarding this type of industry, the slaughter of poultry produces on average 25 to 50 liters of water per head, bovine slaughter generates 2500 liters per head, and pig slaughter requires 1200 liters per head (Maldaner 2008).

The effluents of the meat product industry contain large amounts of animal remains, fragments of viscera and tissue, blood, and fat. This waste leads to high levels of suspended solids, organic matter, organic and ammoniacal nitrogen, phosphorus, COD, and $\mathrm{BOD}$, in addition to detergents and disinfectants used for plant cleaning operations, contributing significantly to the pollution of water sources (Scarassati et al. 2003, Mees 2006, Maldaner 2008, Nogueira 2010). Furthermore, and due to its constitution, the effluents are highly fetid and quickly decompose (Nogueira 2010), possibly triggering the process of eutrophication when released directly into the water body (Mees 2006).

Many meatpacking plants launch the effluents directly into watercourses. These effluents may be diluted, according to the size of the river and volume of water, which can minimize the environmental 
impact (Maldaner 2008); however, this wastewater must be appropriately treated before being released (Scarassati et al. 2003).

The reality of industrial effluent treatment is highly diverse; although it is theoretically possible to treat effluents to meet any legal standard and permit their release into watercourses, there are several limiting factors in the everyday activities of the plants, such as high costs and technological deficiencies (Schoenhals 2006).

Facing water pollution caused by the lack of appropriate treatment for effluents, the necessity to ensure effective effluent treatment emerges. These considerations reveal the need to enhance and monitor the treatment of effluents, and establish more efficient, cost-effective methods. According to Bhat et al. (2019) efficient biomonitoring of effluents for its treatments using eco-friendly technologies could be beneficial to reduce the pollution of water ecosystem.

The most widely used method to assess wastewater pollution levels and consequently predict environmental risks are physical and chemical analyses, which identify and quantify the concentrations of toxic substances, and ecotoxicological tests, which verify the effect of these substances on living organisms (Costa et al. 2008). Toxicity tests are important to evaluate the bio-efficiency of the treatments applied to effluents, considering that pollutant degradation products can be more toxic than the compounds of origin (Bilal et al. 2016a, b).

It is recommended that the toxic effect of a sample be evaluated by more than one species, preferably belonging to different trophic levels of the food chain (Luíz et al. 2012), such as the immobility/mortality test with Artemia salina L. and the micro shellfish and cytotoxicity test with the vegetable Allium cepa $\mathrm{L}$. The test with $A$. salina is fast and inexpensive, it is easy to handle and maintain, and is sufficiently reliable (Hirota et al. 2012, Libralato et al. 2016, Noreen et al. 2017). The test with $A$. cepa is also inexpensive and reliable, and is in agreement with other tests for genotoxicity, aiding studies to prevent damage to human health (Iqbal et al. 2019).

Thus, the aim of the present study was to analyze the toxicity of raw and treated effluents of a meatpacking and a textile plant in the southwest of the state of Paraná, using the immobility/mortality test with Artemia salina L. as bioindicator, and the cytotoxicity test with Allium cepa $\mathrm{L}$. to verify whether the treatment applied by both plants was efficient and resulted in diminished effluent toxicity. Moreover, we sought to establish the physical and chemical parameters of the raw and treated effluents to assess the effectiveness of the treatments. Therefore, this study can provide information about the effectiveness of the conventional system of treating effluents currently used in the textile and meatpacking plants, to prevent environmental harm and public health problems.

\section{MATERIALS AND METHODS}

\section{Sample collection}

The liquid effluents from two industries located in the southwestern region of the Paraná state were selected for analysis, being one a meatpacking plant and the other a textile facility. The liquid effluents from both industries were evaluated before and after the treatment performed by each one. One collection of the samples was performed with a stainless-steel bucket previously sanitized and sterilized with a capacity of ten liters. Eight liters of liquid were collected from the meatpacking effluent, $4 \mathrm{~L}$ from the raw meatpacking effluent (RME) before the treatment, and $4 \mathrm{~L}$ from the treated meatpacking effluent (TME). The same procedure was used to collect samples of the liquid effluent from the textile industry: $4 \mathrm{~L}$ from the raw textile (RTE), and $4 \mathrm{~L}$ from the treated textile effluent (TTE). The samples were stored in resistant plastic vials chemically inert and tightly sealed, correctly cleaned, sterilized and labeled. The vials were maintained under refrigeration in thermal boxes for transportation to the Francisco Beltrão campus of the Federal University of Paraná (UTFPR-FB), where they were transferred to refrigerator and kept at 4 ${ }^{\circ} \mathrm{C}$ until their analysis. With the exception of $\mathrm{pH}$ and temperature analyses, which were made in situ, the others were performed in the Water, Effluent and Biology Laboratory of UTFPR (APHA 1998).

The industrial treatment of the meatpacking effluent was composed of a Parshall trough, whose function was to measure the inlet and outlet flows of the system effluent and to act as a quick mixer, together with a grid responsible for the removal of coarse solids. After this, the effluent passed through a grease box that allowed the removal of the oils and free greases by density difference, followed by a desander, whose objective was to separate the sand and other disposable debris from the liquid medium. Finally, the effluent advanced through three lagoons of anaerobic stabilization.

The treatment of the textile effluent used by the industry was characterized by an equalization tank, a rotary sieve for the mechanical removal of coarse solids, coagulation/flocculation, $\mathrm{pH}$ correction, and the action of an aluminum sulfate coagulating agent, 
followed by biological treatment with mechanic aerators that oxygenate water.

\section{Physical and chemical analyses}

In accordance with the standards established in resolution 430 of the National Environmental Council (CONAMA 2011) and described in the standard methods of the American Public Health Association (APHA 1998), the physical and chemical characterization of the raw and treated effluents examined the following parameters: $\mathrm{pH}$, temperature, chemical oxygen demand (COD), dissolved oxygen (DO), ammoniacal nitrogen, total solids, alkalinity and chloride. The tests of the raw and treated effluent samples from the meatpacking and textile industries were carried out by triplicate. Data were evaluated considering the average between the obtained results of each analysis. The Tukey test was used for statistical analysis $(\alpha=0.05 ; n=3)$.

\section{Mortality/immobility test with Artemia salina $\mathbf{L}$.}

The acute toxicity test with Artemia salina L. was conducted according to the method proposed by Guerra (2001) and Noreen et al. (2017) with modifications. Initially, cysts of $A$. salina, which were obtained from an aquarium store, were incubated in synthetic sea salt solution ( $30 \mathrm{~g} / \mathrm{L})$, with light, and aerated at $25^{\circ} \mathrm{C}$ to induce eclosion.

After hatching, 10 nauplii in instar 2-3 stages were transferred to test tubes containing $2 \mathrm{~mL}$ of the treatment samples, diluted in saline solution in the following concentrations: $100,50,25,12.5,6.2$, and $3.1 \%$, to evaluate the effect of different effluent concentrations. A negative control group was prepared with $2 \mathrm{~mL}$ of saline solution $\left(\mathrm{Co}^{-}\right)$. Four biological replicates were performed, containing 10 organisms in each replicate of each sample group. After $24 \mathrm{~h}$ of incubation at 25 ${ }^{\circ} \mathrm{C}$, the number of dead nauplii was determined by counting those that remained motionless for $20 \mathrm{~s}$.

Toxicity results were expressed as mortality percentage using the following formula: \% toxicity $=$ (average number of immobile individuals in biological replicates in each concentration)/(total mean number of individuals in biological replicates in each concentration $) \times 100$. The mean $( \pm$ standard deviation) number of dead organisms, calculated from the number of dead organisms in each biological replicate of each sample was compared using the Tukey test $(\alpha=0.05 ; n=4)$.

\section{Cytotoxicity test with Allium cepa $\mathrm{L}$.}

The cytotoxicity test with Allium cepa L. was conducted according to the method proposed by Fiskesjö
(1985). The cytotoxicity of the samples was assessed using the meristematic cells of the root of Allium cepa L. as a test system, prepared with Feulgen reaction and stained with the Schiff reagent.

Onion bulbs were placed for four days in jars with water at room temperature, aerated and in the dark, to put down roots. Before each treatment, three roots were collected and fixed (methanol:acetic acid solution 3:1 v:v) to serve as control of the bulb itself $(0 \mathrm{~h})$. Then, the roots of these bulbs were placed in the samples of raw and treated effluents of the meatpacking and textile plants in $100 \%$ concentration for $24 \mathrm{~h}$. After the treatment time, three roots of each onion were removed and fixed $(24 \mathrm{~h})$. The remaining roots were washed, and the bulbs were placed again in filtered water to recover for $24 \mathrm{~h}$, after which the roots were removed and fixed $(48 \mathrm{~h})$. In the negative control group, the onions remained in filtered water during the entire sampling time.

Next, the roots were prepared in stages involving washing, hydrolysis with hydrochloric acid $(\mathrm{HCl} 1 \mathrm{~N}$ at $60^{\circ} \mathrm{C}$ for $10 \mathrm{~min}$ ) and staining with Schiff's reagent (for $45 \mathrm{~min}$ without light). The meristematic region of the roots was used to build the slides, prepared by maceration, and stained with acetic orcein.

The slides were analyzed in a blind test under a light microscope with a $40 \times$ objective. Five bulbs were used for each control and treated group, and 1000 cells were analyzed per bulb, differentiated according to the mitotic phases (interphase, prophase, metaphase, anaphase, telophase), totaling 5000 cells at the collection times of 0,24 , and $48 \mathrm{~h}$. The mitotic index percentage (MI \%) was calculated using the following formula: $\mathrm{MI} \%=$ (number of dividing cells/ total number of cells analyzed $\times 100$. The percentage of the phase index was calculated by the following formula: number of cells in each phase of the mitotic cell cycle/total number of cells analyzed $\times 100$.

The MIs and the phase index were statistically analyzed by the normality test and ANOVA, followed by the Tukey averages comparison test ( $\alpha=0.05$, $\mathrm{n}=5$ ), using Action 6.2 software.

\section{RESULTS AND DISCUSSION}

Data from the toxicity test with the microcrustacean A. salina (Table I) showed an insignificant number of dead/immobile organisms in the low concentrations tested (3.1, 6.2, 12.5 and $25 \%)$ of the raw and treated meatpacking and textile effluents, when compared to the average mortality/immobility number of the negative control. However, the 
EFFICIENCY IN EFFLUENT TREATMENTS

TABLE I. MEANS AND STANDARD DEVIATIONS OF THE NUMBER OF DEAD/IMMOBILE Artemia salina L. FOR THE FOUR BIOLOGICAL REPLICATES

\begin{tabular}{|c|c|c|c|c|c|}
\hline Concentration & RME & TME & & RTE & TTE \\
\hline $\mathrm{Co}^{-}(\%)$ & $0.25 \pm 0.50 \mathrm{a}$ & $0.25 \pm 0.50 \mathrm{a}$ & 0.25 & $\pm 0.50 \mathrm{a}$ & $0.25 \pm 0.50 \mathrm{a}$ \\
\hline 3.1 & $2.00 \pm 1.41 \mathrm{abA}$ & $1.00 \pm 1.41 \mathrm{aA}$ & 0.50 & $\pm 1.00 \mathrm{aA}$ & $1.96 \pm 2.62 \mathrm{aA}$ \\
\hline 6.2 & $0.75 \pm 0.95 \mathrm{abA}$ & $1.00 \pm 1.41 \mathrm{aA}$ & 0.75 & $\pm 0.5 \mathrm{aA}$ & $3.42 \pm 4.75 \mathrm{aA}$ \\
\hline 12.5 & $0.91 \pm 0.11 \mathrm{abA}$ & $1.75 \pm 1.50 \mathrm{aA}$ & 1.25 & $\pm 1.25 \mathrm{aA}$ & $0.00 \pm 0.0 \mathrm{aA}$ \\
\hline 25 & $0.75 \pm 0.50 \mathrm{abA}$ & $0.50 \pm 0.58 \mathrm{aA}$ & 0.75 & $\pm 0.95 \mathrm{aA}$ & $0.35 \pm 0.71 \mathrm{aA}$ \\
\hline 50 & $3.20 \pm 0.63 \mathrm{bA}$ & $0.50 \pm 0.58 \mathrm{aA}$ & 2.25 & $\pm 2.87 \mathrm{aA}$ & $2.47 \pm 1.33 \mathrm{aA}$ \\
\hline 100 & $7.66 \pm 1.76 \mathrm{cA}$ & $9.25 \pm 1.50 \mathrm{bA}$ & 10 & $\pm 0.00 \mathrm{bA}$ & $9.16 \pm 1.67 \mathrm{bA}$ \\
\hline
\end{tabular}

Note: means followed by the same letter do not differ statistically between themselves according to the Tukey test at $5 \%$.Lowercase letters are used to compare different concentrations within the same treated group and uppercase letters to compare the concentration of different treatments.

$\mathrm{Co}^{-}$: negative control group, RME: raw meatpacking effluent, TME: treated meatpacking effluent, RTE: raw textile effluent, TTE: treated textile effluent

percentage of toxicity (Table II) varied from 7.5 to $76.6 \%$ and 5 to $92.5 \%$ in the raw and treated meatpacking effluents, respectively, and from 7.5 to $100 \%$ and from 0 to $91.6 \%$ in the raw and treated textile effluents, respectively.

TABLE II. TOXICITY PERCENTAGE OF Artemia salina L. TREATED WITH DIFFERENT CONCENTRATIONS OF EFFLUENTS

\begin{tabular}{ccccc}
\hline Concentration & RME (\%) & TME $(\%)$ & RTE $(\%)$ & TTE $(\%)$ \\
\hline Co $^{-}$ & 2.5 & 2.5 & 2.5 & 2.5 \\
$3.1 \%$ & 20 & 10 & 5.0 & 19.57 \\
$6.2 \%$ & 7.5 & 10 & 7.5 & 34.17 \\
$12.5 \%$ & 9.15 & 17.5 & 12.5 & 0 \\
$25 \%$ & 7.5 & 5.0 & 7.5 & 3.55 \\
$50 \%$ & 32.07 & 5.0 & 22.5 & 24.75 \\
$100 \%$ & 76.6 & 92.5 & 100 & 91.65 \\
\hline
\end{tabular}

RME: raw meatpacking effluent, TME: treated meatpacking effluent, RTE: raw textile effluent, TTE: treated textile effluent, $\mathrm{Co}^{-}$: negative control group

Thus, the highest concentrations of raw meatpacking effluents $(50 \%$ and $100 \%)$ and treated meatpacking effluents $(100 \%)$ caused the mortality of organisms, statistically different from the negative control (Table I), with percentage of toxicity form 32 to $92.5 \%$. In addition, the highest concentration of the raw and treated meatpacking effluents was statistically different from the other concentrations evaluated in the same effluents, indicating that the dilution is related to the non-toxicity of the effluents to $A$. salina. A similar effect was observed by Silva (2011) in a toxicity test with Daphnia similis, where large concentrations of raw and treated meatpacking effluents were needed to trigger toxic effects. The work of Lied and Rodrigues (2012) with the effluents of a meatpacking plant and Daphnia magna as a bioindicator, also proved that the tested effluent samples showed toxicity.

Despite the reduced toxic effects of the raw meatpacking effluent in comparison to the treated effluent, this is still toxic, so other treatments are evidently required in the plants to fully eliminate toxicity. Even though, the crude and treated effluents presented average number of similar dead organisms in the comparison of the same concentration for the two evaluated effluents. Nogueira (2010) also demonstrated toxicity, corroborating these results; he used the acute toxicity test with Daphnia similis in the treated effluent of a meatpacking plant in different months of the year.

For the textile effluent, the raw and treated effluents were statistically toxic in the highest concentration tested (100\%) (Table I), with a toxicity percentage $>91 \%$ (Table II). Furthermore, there was no statistical difference in the number of dead organisms of the treated textile effluents when compared with the raw effluents in the different concentrations; however, the highest concentration of the raw and treated textile effluent was statistically different from the other concentrations evaluated in the same effluent, indicating that the dilution of the effluent allows the dilution of its possible toxic agents to A. salina. Bilal et al. (2016a) also confirmed the toxicity of a textile effluent using A. salina as bioindicator, but noted that after this effluent was treated with manganese peroxide in Chitosan spheres, the toxicity was reduced, unlike the findings of this study with the treatment applied 
by the plant with the coagulating agent aluminum sulfate. Punzi et al. (2015a) also showed that the use of biological treatment followed by photo-Fenton oxidation might have reduced the toxicity of treated textile effluents for the bioindicator A. salina, suggesting that advanced oxidation is effective in degrading organic compounds and removing the toxicity of textile effluents. In this way, data suggest that some additional treatment should be carried out in the textile effluent of the present study.

In this study, the toxicity of effluents in high concentrations may be caused by the presence of detergents, which hinders the gas exchange between the water surface and the atmosphere, preventing oxygenation, possibly leading to the death of aquatic organisms and affecting and deconstructing the cell membranes of microorganisms (Romanelli 2004). A similar effect may be caused by a high content of oils and greases in the meatpacking effluent, which may cause toxicity to microorganisms and solidify at low temperatures, generating waste in the receiving body (Rigo 2004). According to Jadhav et al. (2010), the major chemical pollutants present in textile wastewater are dyes containing carcinogenic amines, toxic heavy metals, pentachlorophenol, chlorine bleaching, halogen carriers, free formaldehyde, biocides, fire retardants, and softeners. These synthetic dyes do not degrade easily and have a long half-life, as can be observed by the high color values obtained in the physical and chemical analyses (Table III).

According to Zahaira and Suteu (2012), ecotoxicological studies indicated that over $18 \%$ of 200 dyes tested in England showed significant inhibition of the respiration rate of wastewater bacteria from sewage. This can affect the entrance of light into the environment and the gas exchange, resulting in toxicity to different aquatic organisms, as already demonstrated in the works of Punzi et al. (2015b) with textile effluents in A. salina and Vibrio fischeriin. Oliveira et al. (2018) also studied the ecotoxicity of textile dyes: both Direct Black 38 (azo dye) and Reactive Blue 15 (copper phthalocyanine dye) caused acute toxicity and genotoxicity to aquatic organisms; however, DB38 DB38 was the most toxic dye due to its lethal toxicity on $A$. salina and capacity to induce DNA damage in Daphnia magna.

Moreover, meatpacking and textile effluents contain, among other compounds, organic matter, as demonstrated by the high values of chemical oxygen demand and total soluble solids of the effluents (Table III) evaluated in this study, which may affect the survival of organisms. With respect to the total solids content, despite the decline in

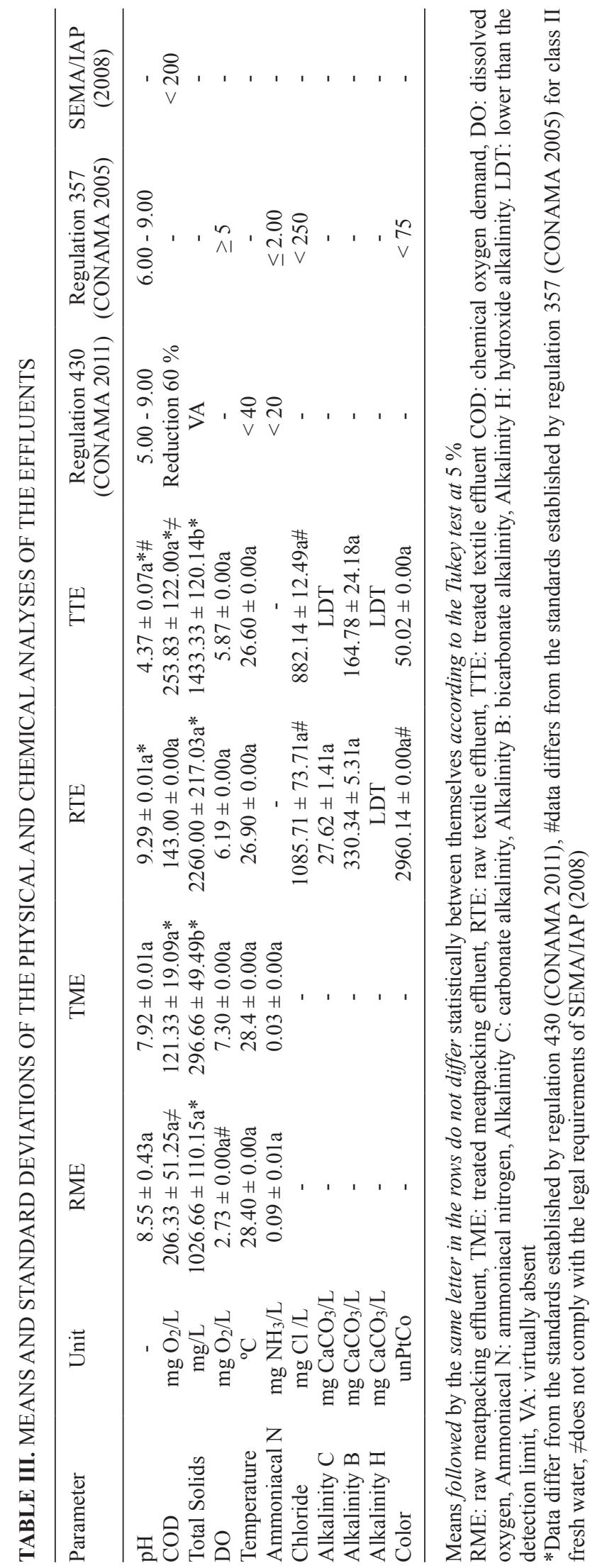


content of the raw meatpacking and textile effluents compared to the treated effluents $(\mathrm{RME}=1026.66 \pm$ $110.15 \mathrm{mg} / \mathrm{L} ; \mathrm{TME}=296.66 \pm 49.49 \mathrm{mg} / \mathrm{L} ; \mathrm{RTE}=$ $2260.00 \pm 217.03 \mathrm{mg} / \mathrm{L} ; \mathrm{TTE}=1433.33 \pm 120.14 \mathrm{mg} / \mathrm{L}$ ) (Table III), values do not fall within those established by CONAMA (2011) in resolution 430 (virtually absent), which states the conditions and standards for the establishment of effluents. Rigo (2004) recorded higher total solids than the values found in this study for the meatpacking effluents after flotation (107 $927.00 \mathrm{mg} / \mathrm{L}$ ). This parameter, together with COD, is very important because solids may come from remnants of tissues and viscera or other industrial and treatment processes, which may directly affect the watersheds in which they are dumped. This may have resulted in the toxicity of the effluent under study at high concentrations for A. salina.

COD is one of the most important physical and chemical parameters considered by the Secretariat of Environment and Water Resources of Paraná and the Environmental Institute of Paraná (SEMA/ IAP), which state that the maximum COD for textile effluents is $200 \mathrm{mg} / \mathrm{L}$ (SEMA/IAP 2008). Thus, the treated textile effluents of this study fail to comply with this standard $\left(\mathrm{TTE}=253.83 \pm 0.00 \mathrm{mg} / \mathrm{L} \mathrm{O}_{2}\right)$, and are very similar to those obtained by Hemachandra and Pathiratne (2016) for treated textile effluents of plant $1\left(249.0 \mathrm{mg} / \mathrm{L} \mathrm{O}_{2}\right)$ and $2\left(434.0 \mathrm{mg} / \mathrm{L} \mathrm{O}_{2}\right)$. Also, they fail to comply with the requirements of resolution 430 (CONAMA 2011) to reduce $60 \%$ of COD; in fact, the COD increased after the effluent was treated at the plant $(\mathrm{RTE}=143.00 \pm 0.00 \mathrm{mg} / \mathrm{L}$ $\mathrm{O}_{2} ; \mathrm{TTE}=253.83 \pm 0.00 \mathrm{mg} / \mathrm{L} \mathrm{O}_{2}$ ), possibly due to the formation of byproducts that are more toxic than the initial composition of the effluents.

In addition to the data presented above, the amount of DO did not increase in the treated textile effluents in comparison with the raw textile effluents $\left(\mathrm{RTE}=6.19 \pm 0.00 \mathrm{mg} / \mathrm{L} \mathrm{O}_{2}\right.$; TTE $=5.87 \pm$ $0.00 \mathrm{mg} / \mathrm{L} \mathrm{O}_{2}$ ), although it was higher than the value established by CONAMA (2005) for water class II, which is the case of the river where this textile effluent was discharged ( $\mathrm{DO}>5 \mathrm{mg} / \mathrm{L} \mathrm{O}_{2}$ ). This finding is unfavorable, since DO is essential for the oxidation of organic matter and the respiration of the aerobic organisms that inhabit the location where the effluent is discharged (Pinto et al. 2010). In contrast, the DO of the present study was lower than the value observed by Hemachandra and Pathiratne (2016) for the treated effluents of plant $1\left(7.8 \mathrm{mg} / \mathrm{L} \mathrm{O}_{2}\right)$ and greater than the value obtained for plant $2(0.3 \mathrm{mg} / \mathrm{L}$ $\mathrm{O}_{2}$ ). The decrease in DO corroborates the increase in COD, since organisms use the DO to degrade organic matter. Evidently, the treatment used in the textile plant must be reviewed, since something is increasing the COD during the process, thus reducing the DO. According to Beltrame (2000), residual dyes linked to organic and inorganic chemical assistants are responsible for the color, dissolved solids, and high COD values in textile effluents.

Regarding the meatpacking effluents, data show that despite the $41.19 \%$ reduction of COD when comparing the raw and treated meatpacking effluents $\left(\mathrm{RME}=206.33 \pm 51.25 \mathrm{mg} / \mathrm{L} \mathrm{O}_{2} ; \mathrm{TME}=121.33\right.$ $\pm 19.09 \mathrm{mg} / \mathrm{L} \mathrm{O}_{2}$ ) (Table III), the plant also failed to reach the established legal values (CONAMA 2011), which stipulate that this parameter should be reduced by $60 \%$ (from raw to treated effluents). However, the treated effluent reached the limit established by SEMA/IAP (2008) (COD < $200 \mathrm{mg} / \mathrm{L}$ $\mathrm{O}_{2}$ ) for discharge into water bodies. Radoll (2013) obtained more satisfactory results, with a more than $60 \%$ reduction in the treated effluents of the studied meatpacking plants and lower COD values (plant $\mathrm{A}=$ $24 \mathrm{mg} / \mathrm{L} \mathrm{O}_{2}$, plant $\mathrm{B}=37 \mathrm{mg} / \mathrm{L} \mathrm{O}_{2}$ ). These data may be justified by the greater number of treatment steps of plants A and B compared to the present study. In contrast, the COD values of the raw effluents in the study of Radoll (2013) (plant A $=8680 \mathrm{mg} / \mathrm{L} \mathrm{O}_{2}$, plant $\mathrm{B}=7620 \mathrm{mg} / \mathrm{L} \mathrm{O}_{2}$ ) were higher than those of the present study. According to Nogueira (2010), COD can be affected by blood, fat, feathers (in the case of poultry slaughterhouses), scraps of fabric, viscera, and gizzards, all of which directly affect regional ecosystems if discarded into rivers, and have resulted in the toxicity for $A$. salina of the raw and treated textile effluents, including $50 \%$ concentrations of the raw effluent.

However, in relation to the OD content, after the effluents were treated in the meatpacking plants where the samples of this study were collected, these effluents had higher DO levels $(\mathrm{RME}=2.73$ $\left.\pm 0.00 \mathrm{mg} / \mathrm{L} \mathrm{O}_{2} ; \mathrm{TME}=7.30 \pm 0.00 \mathrm{mg} / \mathrm{L} \mathrm{O}_{2}\right)$, and a value within the minimum value established by CONAMA (2005) for class 2 fresh water (DO > $5.0 \mathrm{mg} / \mathrm{L} \mathrm{O}_{2}$ ), the same class as the receiving body of the plant's effluents. Radoll (2013) also noted that after the meatpacking effluent was treated, there was an increase in DO (plant $\mathrm{A}$, raw $=0.34 \mathrm{mg} / \mathrm{L} \mathrm{O}_{2}$, treated $=1.27 \mathrm{mg} / \mathrm{L} \mathrm{O}_{2}$; plant $\mathrm{B}$, raw $=0.28 \mathrm{mg} / \mathrm{L}$ $\mathrm{O}_{2}$, treated $=1.44 \mathrm{mg} / \mathrm{L} \mathrm{O}_{2}$ ), although the increase in DO of the effluents in this study was greater. This result can be justified by the lower COD values of this study, as a lower amount of oxygen is required for its degradation; however, this can also be related to the adopted treatment process. 
In general, data of the physicochemical analysis (Table III) show the efficiency of the treatment applied by the meatpacking plant. According to these data, there was a reduction of $\mathrm{pH}$, ammoniacal nitrogen, COD, and total solids, as previously discussed. However, only the data of $\mathrm{pH}(\mathrm{RME}=8.55 \pm 0.43$; $\mathrm{TME}=7.92 \pm 0.01)$, temperature $(\mathrm{RME}=28.4 \pm$ $0{ }^{\circ} \mathrm{C}$; TME $=28.4 \pm 0{ }^{\circ} \mathrm{C}$ ), and ammoniacal nitrogen $\left(\mathrm{RME}=0.09 \pm 0.01 \mathrm{mg} \mathrm{NH}_{3} / \mathrm{L} ; \mathrm{TME}=0.00 \pm 0.03\right.$, $\mathrm{mg} \mathrm{NH}_{3} / \mathrm{L}$ ) are within the levels established by resolution 430 (CONAMA, 2011) (pH between 5.0-9.0, temperature under $40^{\circ} \mathrm{C}$, ammoniacal nitrogen under $20 \mathrm{mg} \mathrm{NH}_{3} / \mathrm{L}$ ). In accordance with this resolution, the above mentioned parameters will not affect the water quality of rivers that receive the treated effluents since they are below those established by resolution 357 (CONAMA 2005) for class II fresh water $(\mathrm{pH}=6-9$, ammoniacal nitrogen below $2.0 \mathrm{mg} \mathrm{NH}_{3} / \mathrm{L}$ ).

The $\mathrm{pH}$ of the meatpacking effluent in this study is higher than the $\mathrm{pH}$ found by Radoll (2013) in the assessment of two meatpacking plants. The author recorded a pH of 7.02 (plant A) and 6.80 (plant B) in the raw effluents, as well as a $\mathrm{pH}$ of 6.77 in the effluent of plant A with a treatment consisting of an anaerobic lagoon, two facultative ponds in series and a pond of maturation, and of 6.30 in the effluent of plant $\mathrm{B}$, whose treatment consisted of an anaerobic lagoon followed by a facultative lagoon and two lagoons with aeration. In contrast, the temperatures of the raw effluents of the plants studied by Radoll (2013) (plant $\mathrm{A}=27.5^{\circ} \mathrm{C}$, plant $\mathrm{B}=26.7^{\circ} \mathrm{C}$ ) were similar to those of the present study. With respect to total nitrogen, Ribeiro et al. (2013) found higher values for the treated effluent of a bovine slaughterhouse $\left(1.53 \mathrm{mg} \mathrm{NH}_{3} / \mathrm{L}\right)$ than the values recorded in the present study.

The physical and chemical analyses of the textile effluents (Table III) also show that after the treatment of raw effluents, there was a reduction of $\mathrm{pH}$ (RTE $=9.28 \pm 0.01$; TTE $=4.37 \pm 0.07)$, concentration of chlorides $(\mathrm{RTE}=1085.71 \pm 73.71 \mathrm{mg} / \mathrm{L} \mathrm{Cl}$; TTE $=$ $882.14 \pm 12.49 \mathrm{mg} / \mathrm{L} \mathrm{Cl}$ ), carbonate alkalinity (RTE $=27.62 \pm 1.41 \mathrm{mg} / \mathrm{LCaCO}_{3} ; \mathrm{TTE}=0.00 \pm 0.00 \mathrm{mg} / \mathrm{L}$ $\left.\mathrm{CaCO}_{3}\right)$, bicarbonate alkalinity $(\mathrm{RTE}=330.34 \pm 5.31$ $\mathrm{mg} / \mathrm{L} \mathrm{CaCO}_{3} ; \mathrm{TTE}=164.78 \pm 24.18 \mathrm{mg} / \mathrm{L} \mathrm{CaCO}_{3}$ ), color $(\mathrm{RTE}=1960.14 \pm 0.00 \mathrm{unPtCo}$; TTE $=50.02$ $\pm 0.00 \mathrm{unPtCo}$ ), and total solids, the latter showing a statistical difference using the Tukey test. However, only the data of temperature $(\mathrm{RTE}=26.90 \pm$ $0.00{ }^{\circ} \mathrm{C}$; TTE $=26.60 \pm 0.00^{\circ} \mathrm{C}$ ) and color were within the levels established by resolution 430 (CONAMA 2011) (temperature under $40^{\circ} \mathrm{C}$, color under $75 \mathrm{mg}$ unPtCo). Furthermore, the data of the present study are similar to those obtained by Hemachandra and Pathiratne (2016) for treated textile effluents (plant $1=30.5^{\circ} \mathrm{C}$, plant $2=29.3^{\circ} \mathrm{C}$ ).

It is worth mentioning that the reduction in $\mathrm{pH}$ of the raw effluent is outside the limits established by resolution 430 ( $\mathrm{pH}$ between 5.0-9.0) (CONAMA 2011). Possibly, some stage of the treatment applied by the textile industry resulted in the decrease of the $\mathrm{pH}$. These data may have contributed to the toxicity of the treated effluent since low $\mathrm{pH}$ (acids) hinder the survival of organisms (Fuhrmann et al. 2019). Besides that, in comparison to other textile effluents, such as those syudied by Hemachandra and Pathiratne (2016) for two different plants (plant $1=8.38$, plant $2=8.15$ ), the $\mathrm{pH}$ of the treated textile effluents in this study had the lowest value of all tested effluents.

Thus, the discharge of these effluents in rivers can cause changes in the ecological health of the receiving waters, hence the importance of aggregating ecotoxicological analyses to the verification of physical and chemical parameters (Hemachandra and Pathiratne 2016), mainly because effluents may still contain substances potentially toxic to aquatic organisms, even though they remain within the limits of legislation in physical and chemical terms, as demonstrated in the immobility/mortality test with A. salina.

However, organisms of different trophic levels can respond in various ways to toxic pollutants, so the use of different bioindicators in the ecotoxicological evaluations makes it possible the know the level at which the pollutant interacts with the organism and the susceptibility of the latter (Arias et al. 2007, Libralato et al. 2016).

Thus, the results of the cytotoxicity test with $A$. cepa (Fig. 1) showed that neither the raw or treated effluents $(24 \mathrm{~h})$ of the meatpacking or textile plants had cytotoxic effects on this vegetal bioindicator, since it presented mitotic indices similar to those of the negative control ( $24 \mathrm{~h}$ ) and the control of the bulb itself $(0 \mathrm{~h})$, and did not influence the cell divisions of the onion. In addition, the observation of the different mitotic phases (Table IV) and the percentage of phase index found in the raw and treated effluents of the meatpacking and textile plants, show that even within the different phases of the mitotic cell cycle (interphase, prophase, metaphase, anaphase, and telophase), there was no statistical difference between the control group ( $24 \mathrm{~h})$, the control of the bulb ( $0 \mathrm{~h})$ and the groups treated $(24 \mathrm{~h})$ when compared with the Tukey test $(\alpha=0.05)$. In addition, no statistical change was observed between the mitotic indices 


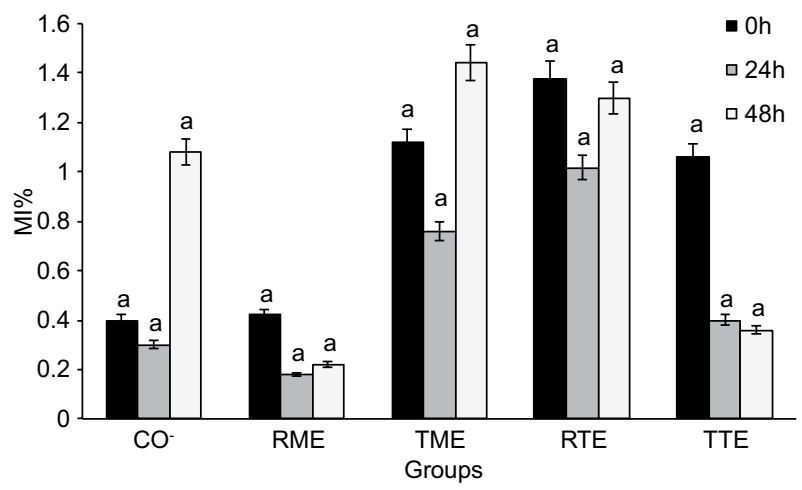

Fig. 1. Mitotic index percentages (MI \%) for the collection times of 0,24 , and $48 \mathrm{~h} . \mathrm{Co}^{-}$: negative control group, RME: raw meatpacking effluents, TME: treated meatpacking effluents, RTE: raw textile effluents, TTE: treated textile effluents. Means followed by the same letter in the columns do not differ statistically between themselves according to the Tukey test at $5 \%$

(Fig. 1) and the phase index (Table V) between raw and treated effluents or between the textile and the meatpacking effluents, despite differences in the physical and chemical analyses (Table III) of these studied effluents.

Radoll (2013) obtained different results than those of this study when assessing the raw and treated effluents of two meatpacking plants and observed significant genotoxic damage of these effluents on fish used as bioindicators. In the case of textile effluents, Hemachandra and Pathiratne (2016) also obtained results different to those in study, since their tests showed cytotoxicity even at dilutions of 1:8 of treated textile effluents with $A$. cepa and Oreochromis niloticus As bioindicators.

However, it can be observed that the mitotic index percentage (that is, of the onion cell divisions) dropped from the raw textile effluent $(\mathrm{MI}=1.01 \%)$ to the treated effluent $(\mathrm{MI}=0.40 \%)$. Moreover, in the recovery time of this bioindicator, it was the only treatment that did not show a reduction of the mitotic index from $24 \mathrm{~h}(\mathrm{MI}=0.40 \%)$ to $48 \mathrm{~h}(\mathrm{MI}=0.36 \%)$. These results may be justified by the decrease in the $\mathrm{pH}$ from the raw to the treated textile effluent, as well as the increase in COD (Table III), which may have enlarged the amount of potentially toxic substances in the effluent, indicating that new treatment steps should be applied or even improved in order to avoid toxicity thereof. Alvim et al. (2011) used A. cepa to assess the cytotoxic potential of raw and treated effluents of two textile plants in southern Minas Gerais and noted a lower mitotic index in all the treated effluent concentrations when compared to raw effluent concentrations. In contrast, Bilal et al. $(2016 \mathrm{a}, \mathrm{b})$

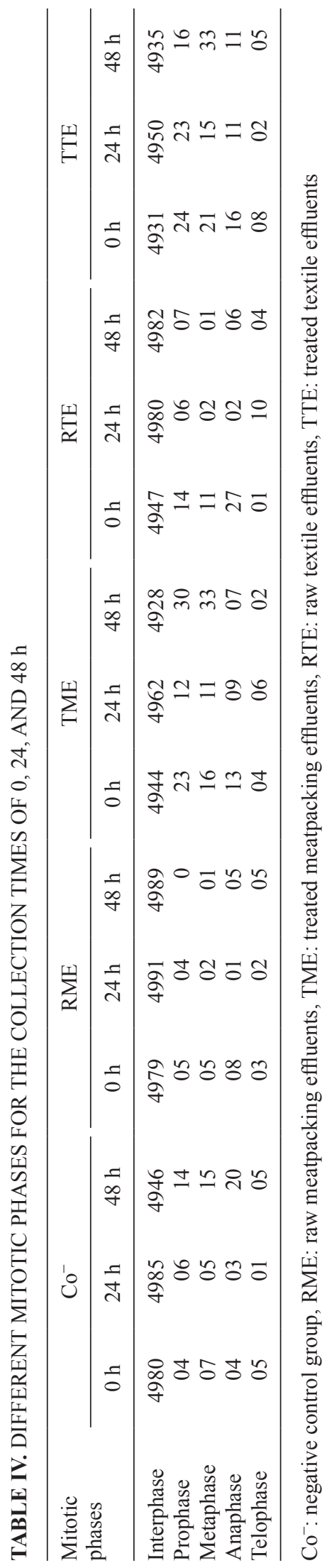




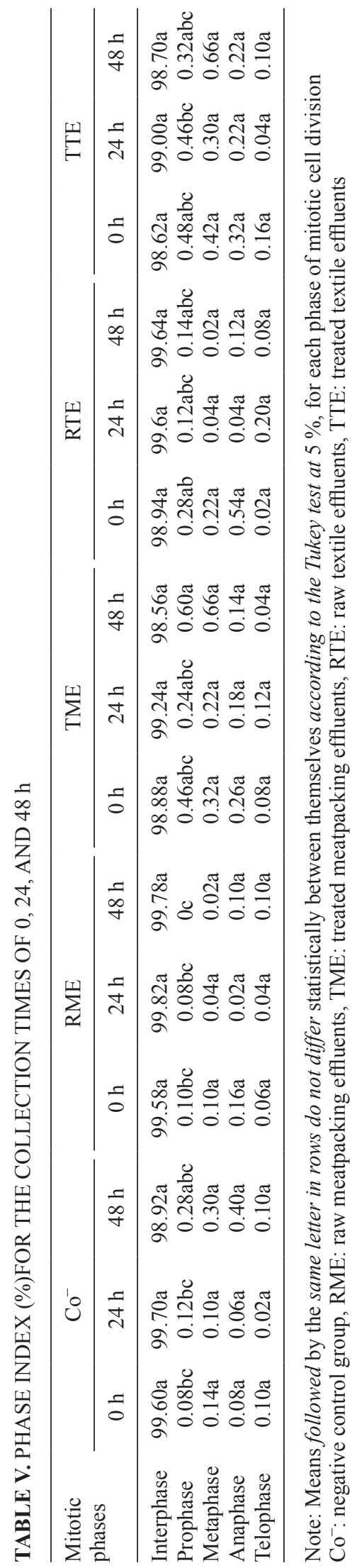

obtained different results to those of this study when treating textile effluents with manganese peroxide encapsulated in $\mathrm{Ca}$-alginate or in chitosan beads. In this case, the treated effluent increased the average mitotic index percentage of the onion roots. Iqbal and Nisar (2015) treated textile effluents with gamma radiation and hydrogen peroxide, finding a $50 \%$ reduction in toxicity from the raw effluent to the treated effluent. These studies indicate that adequate treatment of effluents can reduce the formation of cytotoxic agents or eliminate existing ones.

Therefore, considering the importance that physical, chemical and toxicological parameters remain within values that are not harmful to the environment, it is indicated that additional treatments should be carried out in textile and meatpacking effluents. The analyses carried out in this study are fundamental to develop and improve treatments and the results contribute to highlight the importance for industries in regard to effluent disposals and the observance of standards.

\section{CONCLUSION}

Results show that only the lowest concentrations $(3.1,6.2,12.5$ and $25 \%)$ of the raw and treated effluents of the meatpacking and textile industries were not toxic to $A$. salina. The highest concentrations of raw meatpacking effluents (50 and $100 \%$ ), the highest concentration of raw textile effluents $(100 \%)$ and the highest concentration of the treated meatpacking and textile effluents $(100 \%)$ were toxic to this bioindicator. Thus, it is evident that additional treatment measures are required in both plants to fully eliminate toxicity, mainly because the values of physical and chemical parameters (total solids content [for treated meatpacking and textile effluents], COD [for treated meatpacking and textile effluents], chlorides, carbonate alkalinity and bicarbonate alkalinity [for treated textile effluents]) are not being effectively reduced in order to meet the levels required by the current legislation. Other parameters $(\mathrm{pH}$, temperature, ammoniacal nitrogen and color) remain within the limits established by the national legislation.

None of the treatments had a cytotoxic effect on A. cepa, because they did not change statistically the mitotic index and the index of phases. However, the mitotic index percentage dropped from the raw textile effluent to the treated effluent. Thus, the results stress the importance of effectively treating effluents to prevent environmental harm and health problems in the area of discharge. 
This study suggests that some additional treatments should be carried out in the textile and meatpacking effluents. Monitoring the effectiveness of these measures is fundamental for the development of new techniques that enhance the results of industrial effluents treatment. This may reflect in the development of new treatments that are more effective and have a better cost-benefit.

\section{REFERENCES}

Alvim L.B., Kummrow F., Beijo L.A., Lima C.A.A and Barbosa S. (2011). Evaluation of cytotoxotoxicity of textile effluents using Allium cepa L. Ambi. Agua 6 (2), 255-265.

DOI: $10.4136 /$ ambi-agua. 198

APHA (1998). Standard methods for the examination of water and wastewater. 20th ed. American Public Health Association. Washington, USA, 1325 pp.

Arias A.R.L., Buss D.F., Alburquerque C., Inácio A.F., Freire M.M., Egler M., Mugnai R. and Baptista D.F. (2007). Use of bioindicators for assessing and monitoring pesticides contamination in streams and rivers. Ciênc. Saúde Coletiva 12 (1), 61-72.

DOI: $10.1590 / \mathrm{S} 1413-81232007000100011$

Beltrame L.T.C. (2000). Characterization of textile effluent and treatment proposal. M.Sc. Thesis. Federal University of Rio Grande do Norte. Natal, Brazil, $179 \mathrm{pp}$.

Bhat S.A., Cui G., Li F. and Vig A.P. (2019). Biomonitoring of genotoxicity of industrial wastes using plant bioassays. Bioresour. Technol. Rep. 6, 207-216.

DOI: 10.1016/j.biteb.2019.03.005

Bilal M., Ascher M., Iqbal M., Hu H. and Zhang H. (2016a). Chitosan beads immobilized manganese peroxidase catalytic potential for detoxification and decolorization of textile effluent. Int. J. Biol. Macromol. 89, 181-189.

DOI: 10.1016/j.ijbiomac.2016.04.075

Bilal M., Iqbal M., Hu H. and Zhang X. (2016b). Mutagenicity and cytotoxicity assessment of biodegraded textile effluent by $\mathrm{Ca}$-alginate encapsulated manganese peroxidase. Bioch. Eng. J. 109, 153-161.

DOI: $10.1016 /$ j.bej.2016.01.020

CONAMA (2005). Resolution number 357 of March 17. Conselho Nacional do Meio Ambiente [online]. http:// www.mma.gov.br/port/conama/res/res05/res35705. pdf 18/03/2017.

CONAMA (2011). Resolution number 430, of May 13. Conselho Nacional do Meio Ambiente [online]. http://www.mma.gov.br/port/conama/legiabre. cfm?codlegi $=646$ 18/03/2017.
Costa C.R, Olivi P. and Espindola E.L.G. (2008). Toxicity in aquatic environments: discussion and evaluation methods. Qim. Nova 31 (7), 1820-1830. DOI: $10.1590 / \mathrm{S} 0100-40422008000700038$

Costa A.F.S., Albuquerque C.D.C, Salgueiro A.A. and Sarubbo L.A. (2018) Color removal from industrial dyeing and laundry effluent by microbial consortium and coagulant agents. Process. Saf. Environ. 118, 203-210. DOI: 10.1016/j.psep.2018.03.001

Earnhart D. (2013). Water pollution from industrial sources. Encyclopedia of Energy, Natural Resource, and Environmental Economics 3, 114-120.

DOI: 10.1016/B978-0-12-375067-9.00091-7

Fiskesjö G. (1985). The Allium test-an alternative in environmental studies: The relative toxicity of metal ions. Mutat. Res.-Fund. Mol. M. 197, 243-260. DOI: 10.1016/0027-5107(88)90096-6

Fuhrmann M., Richard G., Quéré C., Petton B. and Pernet F. (2019). Low pH reduced survival of the oyster Crassostrea gigas exposed to the Ostreid herpesvirus 1 by altering the metabolic response of the host. Aquaculture 503, 167-174.

DOI: $10.1016 /$ j.aquaculture.2018.12.052

Guerra R. (2001). Ecotoxicological and chemical evaluation of phenolic compounds in industrial effluents. Chemosphere 44 (8), 1737-1747.

DOI: $10.1016 / \mathrm{S} 0045-6535(00) 00562-2$

Hemachandra C.K. and Pathiratne A. (2016). Combination of physico-chemical analysis, Allium cepa test system and Oreochromis niloticus erythrocyte based comet assay/nuclear abnormalities tests for cyto-genotoxicity assessments of treated effluents discharged from textile industries. Ecotoxicol. Environ. Saf. 131, 54-64.

DOI: 10.1016/j.ecoenv.2016.05.010

Hirota B.C.K., Paula C.S., Miguel O.G. and Miguel M.D. (2012). Toxicity evaluation in vitro: applicability of brine shirimp Artemia Salina lethality assay. Visão Acadêmica 13 (2), 42-48. DOI: 10.5380/acd.v13i2.27834

Iqbal M. and Nisar J. (2015). Cytotoxicity and mutagenicity evaluation of gamma radiation and hydrogen peroxide treated textile effluents using biossays. J. Environ. Chem. Engin. 3 (3), 1912-1917.

DOI: $10.1016 / j$ jece.2015.06.011

Iqbal M., Abbas M., Nisar J. and Nazir A. (2019). Bioassays based on higher plants as excellent dosimeters for ecotoxicity monitoring: A review. Chem. Int. 5 (1), 1-80. DOI: 10.5281 /zenodo. 1475399

Jadhav J.P., Kalyani D.C., Telke A.A., Phugare S.S. and Govindwar S.P. (2010). Evaluation of the efficacy of a bacterial consortium for the removal of color, reduction of heavy metals, and toxicity from textile dye effluent. Bioresour. Technol. 101 (1), 165-173.

DOI: 10.1016/j.biortech.2009.08.027 
Kamali M., Suhas D.P., Costa M.E., Capela I. and Aminabhavi T.M. (2019). Sustainability considerations in membrane-based technologies for industrial effluents treatment. Chem. Eng. J. 368, 474-494.

DOI: 10.1016/j.cej.2019.02.075

Libralato G., Prato E., Migliorec L., Cicero A.M. and Manfra L. (2016). A review of toxicity testing protocols and endpoints with Artemia spp. Ecol. Indic. 69, 35-49. DOI 10.1016/j.ecolind.2016.04.017

Lied E.B. and Rodrigues L.M. (2012). Evaluation of potential impact ecotoxicological of liquid waste from a slaughterhouse refrigerator using Daphnia magna. DAE 188, 22-28. DOI: 10.4322/dae.2014.084

Liu R., Chiu H. M., Shiau C., Yeh R. Y. and Hung Y. (2007). Degradation and sludge production of textile dyes by Fenton and photo-Fenton processes. Dyes. Pigm. 73 (1), 1-6. DOI: 10.1016/j.dyepig.2005.10.002

Luíz Â.M.E., Pinto M.L.C. and Scheffer E. (2012). Color and turbidity parameters related to soil uses and morphometry of the Taquaral River basin, São Mateus do Sul-Pr. Caminhos da Geografia 13 (41), 52-67.

Maldaner T.L. (2008). Survey of the alternatives to minimize the impacts generated by the effluents from slaughterhouses and meatpackings. Monography, University Castelo Branco, Brasília, Brazil, 69 pp.

Mathur N., Bhatnagar P., Mohan K., Bakre P., Nagar P. and Bijarnia M. (2007). Mutagenicity evaluation of industrial sludge from common effluent treatment plant. Chemosphere 67 (6), 1229-1235.

DOI: 10.1016/j.chemosphere.2006.10.073

Mees J.B.R. (2006). Use of water hyacinth (Eichhornia crassipes) in slaughterhouse and refrigerator effluent treatment system and evaluation of its composting. M.Sc. Thesis. State University of Western Paraná. Cascavel, Brazil, 70 pp.

Nogueira T.D. (2010). Acute effects of industrial liquid effluents. M.Sc. Thesis. Federal University of Mato Grosso do Sul. Mato Grosso do Sul, Brazil, 71 pp.

Noreen M., Shahid M., Iqbal M., Nisar J. and Abbas M. (2017). Measurement of cytotoxicity and heavy metal load in drains water receiving textile effluents and drinking water in vicinity of drains. Measurement 109, 88-99. DOI: 10.1016/j.measurement.2017.05.030

Oliveira G.A.R., Leme D.M., Lapuente J., Brito L.B., Porredón C., Rodrigues L.B., Brull N., Serret J.T., Disner G.R., Borràs M., Cestari M.M. and Oliveira D.P. (2018). A test battery for assessing the ecotoxic effects of textile dyes. Chem.-Biol. Interact. 291, 171179. DOI: $10.1016 /$ j.cbi.2018.06.026

Pinto A.L., Oliveira G.H. and Pereira G.A. (2010). Evaluation of efficiency of use of dissolved oxygen as a key indicator of quality of surfacewater basin stream Bom Jardim, Brasilândia/MS. GEOMAE 1 (1), 69-82.
Prabakar D., Suvetha S.K., Manimudi V.T., Mathimani T., Kumar G., Rene E.R. and Pugazhendhi A. (2018). Pretreatment technologies for industrial effluents: Critical review on bioenergy production and environmental concerns. J. Environ. Manage. 218, 165-180. DOI: 10.1016/j.jenvman.2018.03.136

Punzi M., Anbalagan A., Börner R.A., Svensson B.M., Jonstrup M. and Mattiasson B. (2015a). Degradation of a textile azo dye using biological treatment followed by photo-Fenton oxidation: evaluation of toxicity and microbial community structure. Chem. Engin. J. 270, 290-299. DOI: 10.1016/j.cej.2015.02.042

Punzi M., Nilsson F., Anbalagan A., Svenssonc B.M., Jönsson K., Mattiasson B. and Jonstrup M. (2015b). Combined anaerobic-ozonation process for treatment of textile wastewater: Removal of acute toxicity and mutagenicity. J. Hazard. Mater. 292, 52-60.

DOI: 10.1016/j.jhazmat.2015.03.018

Radoll G.P. (2013). Evaluation of genotoxicity in liquid effluents of the refrigeration industry. M.Sc. Thesis. Federal Technological University of Paraná. Curitiba, Brazil, 108 pp.

Ribeiro E.A, Sandri D. and Boêno J.A. (2013). Water quality of stream due to release of effluent from cattle slaughter. Rev. Bras. Eng. Agríc. Ambient. 17 (4), 425-433. DOI: 10.1590/S1415-43662013000400011

Rigo E. (2004). Application of lipases as an aid in the pretreatment of effluents from pig and cattle slaughterhouses. M.Sc. Thesis. Integrated Regional University of Upper Uruguay and Missions. Erechim, Brazil, $95 \mathrm{pp}$.

Romanelli M.F. (2004). Evaluation of the acute and chronic toxicity of ds and surfactants submitted to irradiation with electron beams. M.Sc. Thesis. Nuclear and Energy Research Institute-Autarchy associated with the University of São Paulo. São Paulo, Brazil, $156 \mathrm{pp}$.

Scarassati D., Carvalho R.F., Delgado V.L., Coneglian C.M.R., Brito N.N., Tonso S., Sobrinho G.D. and Pelegrini R. (2003). Treatment of effluents from slaughterhouses and slaughterhouses. Memorias. III Fórum de Estudos Contábeis, Technological Education Center-Campinas State University, Rio Claro, São Paulo, Brazil, 2003.

Schoenhals M. (2006). Evaluation of the efficiency of the flotation process applied to the primary treatment of poultry slaughterhouse effluents. M.Sc. Thesis. Federal University of Santa Catarina. Florianópolis, Brazil, 99 pp.

SEMA/IAP (2008). Parameters of discharges of liquid effluents. Secretaria do Meio Ambiente e Recursos Hídricos do Paraná e Instituto Ambiental do Paraná. Paraná, Brazil, 20 pp. 
Sharma K.P., Sharma S., Sharma S., Singh P.K., Kumar S., Grove R. and Sharma P.K. (2007). A comparative study on characterization of textile waste waters (untreated and treated) toxicity by chemical and biological tests. Chemosphere 69 (1), 48-54.

DOI: 10.1016/j.chemosphere.2007.04.086

Silva M.R.A., Oliveira M.C. and Nogueira R.F.P. (2004). Photo-Fenton applicability in the treatment of ink wastewater industry. Eclét. Quím. 29 (2), 19-26. DOI: $10.1590 / \mathrm{S} 0100-46702004000200003$

Silva P.F. (2011). Evaluation of the efficiency of the treatment system of refrigerator effluents - a case study in Rio Claro/SP. B.Sc. Thesis, Paulista State University Júlio de Mesquita Filho. Rio Claro, Brazil, 129 pp.
Sperling M.V. (2007). Basic principles of sewage treatment, v. 2. IWA Publishing, Belo Horizonte, Brazil, $211 \mathrm{pp}$.

Zahaira C. and Suteu D. (2012). Textile organic dyes - Characteristics, polluting effects and separation/ elimination procedures from industrial effluents - A critical overview. In: Organic pollutants ten years after the Stockholm convention - Environmental and analytical update. Vol. 3. (T. Puzyn, Ed.). Intechopen, London, UK, pp. 55-86.

DOI: $10.5772 / 32373$ 